\begin{tabular}{lcr}
\multicolumn{3}{c}{ Asian Journal of Law and Economics } \\
\hline Volume 3, Issue 1 & 2012 & Article 1 \\
\hline
\end{tabular}

\title{
Law and Finance: What Matters? Hong Kong as a Test Case
}

\author{
Horace Yeung, University of Exeter \\ Flora Xiao Huang, University of Hull
}

\section{Recommended Citation:}

Yeung, Horace and Huang, Flora Xiao (2012) "Law and Finance: What Matters? Hong Kong as a Test Case," Asian Journal of Law and Economics: Vol. 3: Iss. 1, Article 1.

DOI: $10.1515 / 2154-4611.1069$

C2012 De Gruyter. All rights reserved. 


\title{
Law and Finance: What Matters? Hong Kong as a Test Case
}

\author{
Horace Yeung and Flora Xiao Huang
}

\begin{abstract}
This paper, using Hong Kong as a test case, challenges one conventional theory and confirms another one in law and finance study: (i) legal families in relation to stock market development; (ii) transplant effect of foreign laws. Economists, most notably La Porta and colleagues, allege that common law systems can offer superior investor protection and thereby facilitate the rise of financial markets. Undeniably, the legal system of Hong Kong, which was inherited from England, belongs to the common law family and is widely considered as one of Hong Kong's advantages. Nonetheless, the high concentration of family ownership among Hong Kong companies implies that its system is not entirely Anglo-Saxon. Moreover, legal scholars, most notably Pistor and colleagues, claim that the import of laws from a developed system (legal transplantation) will have little impact unless there is such a demand in the first place. Interestingly, for Hong Kong, the transformation of a small fishing village in the mid-nineteenth century to a financial serviceoriented economy nowadays is an illustration of the existence of demand in corporate and financial laws. By absorbing the nutrients from English legal traditions, American style of intense public enforcement and the flexibility of Chinese family businesses, Hong Kong has successfully established itself as one of the most crucial financial centers in the world.
\end{abstract}

KEYWORDS: Hong Kong, law and finance, legal origins, legal transplantation, Chinese family businesses

Author Notes: This paper was presented in the Economic \& Social Research Council (ESRC) Corporate Governance, Regulation and Development Seminar Series, Seminar IV: Corporate Governance and Development on June 5, 2009 and the Asian Law and Economics Association (AsLEA) 2011 Annual Meeting on July 8-9, 2011. We are grateful for all the comments and criticisms received on both occasions. The usual disclaimer applies. 


\section{Introduction}

The primary role of a financial market is to allocate resources efficiently. A market is a developed system which disseminates information about investment projects and can therefore guide investors' funds to better uses. There is a division of roles. A traditional view is that banks finance only well-established, safe borrowers, whereas stock markets can finance risky, productive and innovative projects. Equity markets allow companies to rely more on equity and less on debt, creating a less risky financial structure in the event of an economic downturn. To illustrate the importance of stock markets, some scholars have tried to examine the empirical relationship between stock markets and economic growth. A crosssectional study of 39 countries over the period 1980-1988 by Atje and Jovanovic (1993) has suggested that the relative size of a country's stock market helps to explain the subsequent growth in gross domestic product per capita. Built on Atje and Jovanovic's study, Levine and Zervos (1996) have further confirmed that there is a strong correlation between overall stock market development and longrun economic growth.

Given the importance of a financial market, scholars have been interested in what can spur its development. There has been a new branch of legal scholarship called "law and finance" which commonly involves the use of comparative law and empirical evidence (Siems, 2005, 2007). The seminal work from La Porta et al. in 1997 and the later pieces, which were largely built on the former, have initiated the debate as to whether law matters (La Porta et al., 1997, 1998, 2000). The "law matters" thesis is that investors will feel more comfortable in a protective jurisdiction and they are more willing to surrender funds in exchange for securities. Therefore, the scope of capital markets will be expanded to develop a widely dispersed pattern of share ownership. Conversely, the "law does not matter" story is that strong laws are only a response to the demand from an already well-developed market, instead of the cause of it (Cheffins, 2001; Coffee, 2001). In either case, the correlation between strong securities markets, dispersed ownership and strong legal standards seems real.

As rightly claimed by Farrar (2002), Hong Kong represents an international finance center built on the twin foundations of Anglo-American law and finance and successful Chinese family business. This paper, using Hong Kong as a test case, challenges one conventional theory and confirms another one in law and finance study. First, do legal families matter in relation to stock market development? Although legal origin can explain the rise of financial market in Hong Kong, it cannot account for the high concentration of family/state ownership among Hong Kong companies considering that strong securities markets, dispersed ownership and strong legal standards should be closely associated. Second, the way of how the law has been initially transplanted and 
received (the demand for law) is a more important determinant than the supply of law from a particular legal family (Pistor et al., 2003). This article is structured as follows. Part II is a brief review of the existing literature on law and finance. Then, it looks at the history of Hong Kong's financial market. Subsequently, how Hong Kong has benefited from absorbing the nutrients from the English legal system, the American style of intense public enforcement and the Chinese way of doing business will be examined individually. A conclusion is given in Part VII.

\section{Law and Finance: A Path Dependent Perspective}

There has been a very common assumption in the discussions of financial systems that financial markets are the cutting edge of financial technology and that countries without a highly developed system of financial markets are somehow backward or underdeveloped (Allen \& Gale, 2000: 127). From the stories of Japan and Germany, the two features of Anglo-American capitalism, namely dispersed ownership and large stock markets are not necessarily the prerequisites of prosperity (Levine, 2002). In fact, advocates of the bank-centered system claim that this structure fosters long-term planning, whereas a market-based system is said to encourage short-term expectations of investors and responsive short-term strategies by managers (Black \& Gilson, 1997). Furthermore, in an emerging economy, many institutions necessary for the functioning of product markets, labor markets and financial markets are typically missing or underdeveloped. Business groups, which undertake functions traditionally performed by market institutions in more mature markets, could be seen as a private sector response to the institutional voids in the economy (Khanna \& Palepu, 2004: 12). The characteristics of financial systems seem to differ significantly across countries.

\section{A. The Rivalry of Insider and Outsider Control Models}

Coffee (2001: 3) has indicated that the twentieth century saw the polarization of corporate structure between two rival systems of corporate governance. They are the dispersed ownership and the concentrated ownership systems. The former is characterized by strong securities markets, rigorous disclosure standards and high market transparency. By contrast, the latter is characterized by controlling blockholders, weak securities markets, high private benefits of control, low disclosure and market transparency standards. Black (2001: 784) has shared a similar view that a dual equilibrium exists. In the light of capital markets, there exist two separating equilibria, one of them strong, the other weak. In the weak markets, most honest companies do not issue shares to the public because weak investor protection prevents them from realizing a fair price for their shares. This decreases the average quality of the shares that are issued, which further depresses 
prices and discourages honest issuers from issuing shares. Political demand for stronger investor protection is muted by the relative scarcity of outside investors (Black, 2001: 784).

A "strong market" equilibrium works in another way. Strong investor protection produces high prices, which encourage honest companies to issue shares. This increases share prices and encourages more honest issuers to issue shares. Outside investors then generate political support for strong investor protection (Black, 2001: 784).

The global capital markets will provide companies with incentives to adopt efficient ownership structures. Otherwise, they would be penalized in the capital markets and face hurdles in raising new capital. Of course, there is no doubt that not all companies use capital markets for funds, but rather finance themselves from retained earnings or debt. From a historical perspective, during his investigation of the growth of capital markets around the world, Cassis (2006: 41-42) has discovered two major changes during the second third of the nineteenth century. The first was the increasing concentration of capital. Railway company and joint-stock banks started to appear. The former required substantial investments, whereas the latter had massive resources available. Building the railways led to a considerable development in the capital markets, through issuing securities and listing them on the main stock exchanges. By contrast, the emergence of large banks started the accumulation of financial resources by systematically draining savings. The second change was the strong growth in capital exports, which confirmed the existing hierarchy among the international financial centers. Capital was chiefly exported from the London and Paris markets, whereas New York played a growing role on the international capital market. ${ }^{1}$

Regarding the development of capital markets and corporate structure, Coffee has added that beginning in the last quarter of the nineteenth century and culminating no later than the 1930s, the largest private businesses in both the US and UK were converted into publicly owned corporations (Coffee, 2001: 24-25). As indicated by Roe (1996: 3), the large throughput technologies that developed at the end of the nineteenth century meant that cheaper production accrued to the company with the largest scale. Getting the tremendous outputs from the economies of scale eventually required large capital inputs to build the facilities and distribution system. Individuals, even a small group of them, lacked sufficient capital. In this process, control generally passed from families to the market.

Eventually, those new large-scale enterprises had to draw capital from many dispersed shareholders who demanded diversification in their investment portfolio. The administrative tasks soon became too numerous, too varied and too

\footnotetext{
${ }^{1}$ French capital flowed mainly towards Europe to finance the companies abroad and in the form of loans to governments and British capital flowed towards the high seas to finance the international trade, see Cassis (2006: 61-65).
} 
complex. They required special skills and training which could only be commanded by professional managers. The combination of huge enterprise, concentrated management and dispersed diversified investors shifted corporate control from shareholders to managers. The theory of the separation of ownership and control in modern corporations was suggested by Berle and Means in 1932 (Berle \& Means, 1933). Their thesis was that the separation of ownership from management had resulted in shareholders being unable to exercise any form of effective control over boards of directors, who were theoretically appointed by the shareholders to represent their interests.

\section{B. What Matters?}

The core of law and finance studies lies in looking for the correlations between law and financial development. La Porta et al. (1997, 1998, 2000) have examined the legal rules covering protection of corporate shareholders and creditors, the origin of these rules and the quality of their enforcement in 49 countries. Subsequently, they confirmed that the legal environment, including both legal rules and their enforcement, matters for the size and extent of a country's capital market. It is because a good legal environment protects the potential financiers against expropriation by entrepreneurs. Investors are willing to surrender funds in exchange for securities and therefore expand the scope of capital markets. Based on the findings, they claimed that French civil law countries, with the weakest investor protection, have smaller and narrower capital markets. Such interpretation using legal families, with little regard to each particular country's "demand for law" in the first place, later attracted criticisms from other scholars. ${ }^{2}$ Although the subsequent interpretation of statistical results is controversial, the strong correlation found in the study between investor protection and the development of security markets is often broadly accepted.

Whereas La Porta and colleagues have pointed out the importance of legal foundation in terms of shareholder protection to capital market development, Roe (2003) has indicated that the political economy based theories seem stronger than the legal origins theory. He argues that continental social democracies did not provide institutions that securities markets need because heavy labor pressures disfavor the core value of Anglo-Saxon capitalism, the shareholder wealth

\footnotetext{
${ }^{2}$ See, for example, Pistor et al. (2003) and Siems $(2005,2007)$. A mere categorization of a system as common law or civil law disregards deeper legal structures. Furthermore, as indicated by Spamann (2006), many of the initial results from La Porta et al. $(1997,1998,2000)$ are not robust to the correction of coding errors. Nonetheless, a recent empirical research conducted by Armour et al. (2009a) confirms that common law systems were more protective of shareholder interests than civil law ones, but with an understanding that the effects of legal origin are not as strong as widely supposed.
} 
maximization norms. In social democracies, employees are protected from actions that a company would often take to maximize the shareholder value. The goals between employees and shareholders often do not intersect. Employees prefer high wages and shareholders prefer lower wages. Therefore, Roe's argument is that "where labor's influence is strong, concentrated ownership should persist as a countervailing power and, hence, equity markets should develop less strongly" and he supports his argument by showing the correlation between political orientation and ownership structure (Roe, 2006: 502-503). Some scholars have emphasized the politics and finance view that centralized or powerful governments tend to be incompatible with financial development (Beck et al., 2001). The proper functioning of financial institutions and markets requires limitations on government discretion. The political story given by Roe regarding the success of the US is that low government involvement has always been a tradition and companies experienced less interference. As a result, norms such as shareholder wealth maximization flourished easily.

Although the work of La Porta et al. from a legal perspective and that of Roe from a political perspective have produced a great deal of discussions, the effect of other factors, for example, culture, remains rarely touched. In the opinion of Black (2000), the discussion of corporate governance should base upon a culture of honesty before taking the control and monitoring mechanisms into account. From a cultural perspective, laws and rules are used to prevent uncertainties in the behavior of other people. Therefore, people will look for "a structure in their organizations, institutions, and relationships which makes events clearly interpretable and predictable" (Hofsted, 1994: 116). Within a company, there are laws and rules, which can be either formal or informal, controlling the rights and duties of managers and employees. Culture is inherently largely local and cannot be easily transplanted. Lawton (1996) has argued that whereas the original Western concept of the corporate entity creates a "juristic person" separate and distinct from its member, the culture of a place can entail correspondingly different expectations of a company. On the one hand, there may be certain uniformities of culture and business practices in some English-speaking developed economies owing to the heavy influence from the Anglo-Saxon system. On the other hand, divergences arise from differing socio-political and legal systems in other parts of the world.

\section{The Rise of Hong Kong as an Asian Financial Center}

Hong Kong is certainly one of the most vibrant international financial centers. The Hong Kong Stock Exchange (HKEx) is currently the seventh largest in the world in terms of market capitalization, behind the New York Stock Exchange, the Tokyo Stock Exchange, Nasdaq, the London Stock Exchange, Euronext and 
the Shanghai Stock Exchange (see Figure 1). ${ }^{3}$ There is also a high concentration of banking institutions. Of the world's top 100 banks, 68 have operations in Hong Kong (Hong Kong Government, 2008: 67). Although as a financial center Hong Kong is not the biggest in size, it is arguably one of the best. According to the Global Financial Centers Index, London and New York still lead the field and continue to be the only two truly "global" financial centers (City of London \& $\mathrm{Z} /$ Yen Group, 2009). However, Hong Kong, being the third in the overall ranking, has been predicted to pose the greatest threat among Asian cities to the dominance of London and New York (Financial Times, 2008). Hong Kong is the strongest contender because of its historic roots in finance and its ability to tap the Chinese market. ${ }^{4}$ Time Magazine came up with the term "Nylonkong" to describe the extent to which New York, London and Hong Kong linked by a shared economic culture and how they created a financial network which has come to be both the examples and explanations of globalization (Time Magazine, 2008). More recently, the Financial Times even replaced New York and London with Shanghai by using a new term "Shangkong" amid a shift of financial gravity to the east (Financial Times, 2009a). The rise of Hong Kong to its present status is simply a miracle because when Hong Kong was colonized by the British Empire in 1842, Hong Kong was merely a small fishing village.

Figure 1 - Ranking of World Stock Exchanges (Market Capitalization: USD Trillions)

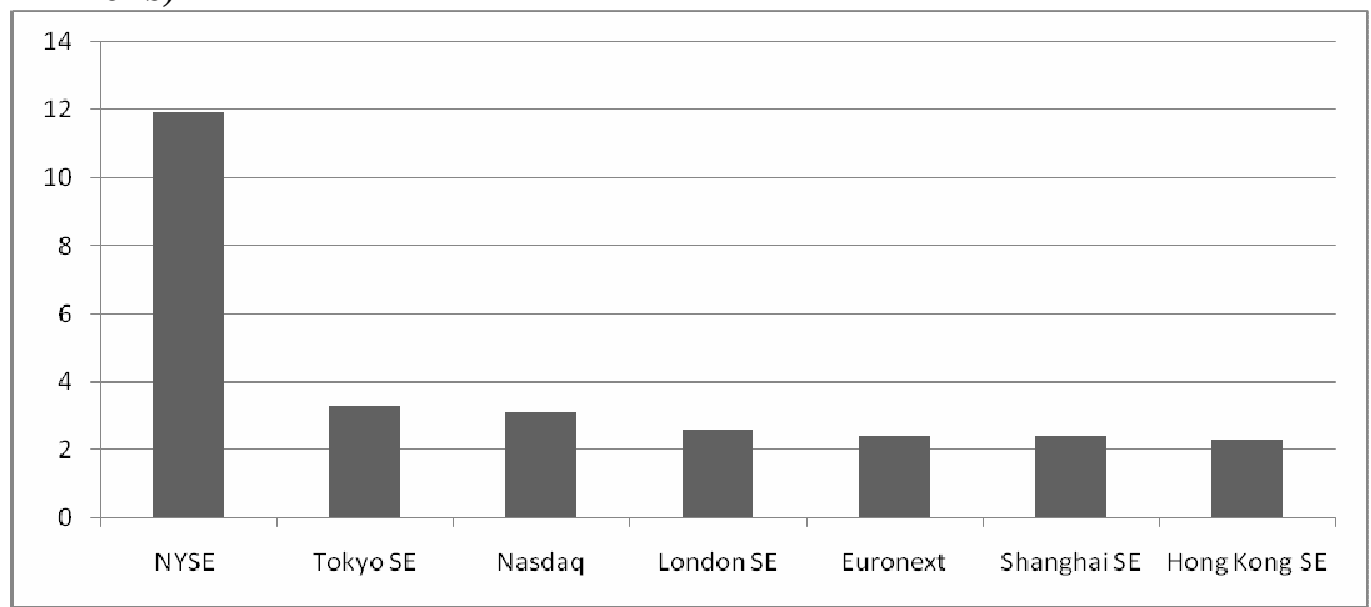

Source: World Federation of Exchanges (as of the end of August 2010).

\footnotetext{
${ }^{3}$ Visit the World Federation of Exchanges, online: <http://www.world-exchanges.org $>$ for the most updated figures.

${ }^{4}$ Trading of company shares in Hong Kong can in fact be traced back to around 1860. In 1891, the Association of Stockbrokers in Hong Kong was formed, changing its name to the Hong Kong Stock Exchange in 1914. See the Securities and Futures Commission (SFC) (2002: 3).
} 
Before the growth of its financial services sector, international trade has long been a defining characteristic of the Hong Kong economy. Beginning in the 1950s, exports of domestically produced light industrial products served as the engine of growth for nearly three decades. 5 Nonetheless, since the late 1970s, many Hong Kong manufacturers relocated their labor-intensive production processes to China to take advantage of the low production costs available there. This forced Hong Kong to transform into a service-oriented economy. Between 1980 and 1997, the percentage of Hong Kong workers employed in services rose from $42.1 \%$ to $79.3 \%$, whereas the percentage employed in manufacturing fell from $45.9 \%$ to $9.8 \%$ (Tao \& Wong, 2002: 2345). In fact, the growth of the Hong Kong Stock Exchange had come even earlier. The Shanghai Stock Exchange which had once been a leading financial center in the Asian region was forced to close down under the Communist regime. The demise of it created an opportunity for Hong Kong to provide a market for the stocks of many of the leading companies once traded in Shanghai (Michie, 2006: 238). From the 1960s onwards, the Hong Kong market began to grow as Hong Kong's economy expanded.

Michie (2006: 267) has indicated that Hong Kong was one location in the 1970s where the securities market did become both firmly established and flourished. By early 1973, the Hang Seng Index in Hong Kong reached a record high of 1,775 points (Securities and Futures Commission, 2002: 8). The subsequent collapse of this speculative boom in 1974 led the government to regulate the rapidly expanding market amid concerns about investor protection and financial stability. Since then, Hong Kong was on the march again except in 1987 when there was a worldwide stock market crash and Hong Kong was not immune. Since the 1990s, the number of initial public offerings (IPOs) activities in Hong Kong has been increasing significantly. Uddin and Wong (2004) have attributed this to three factors: bullish stock market conditions, high growth in the Hong Kong economy and an influx of Chinese investments. The general pattern of the development of the Hong Kong stock market from 1991 is given in Table 1.

\section{Table 1 - Development of Hong Kong's Stock Market 1991-2010}

\begin{tabular}{|l|lll|} 
Year & $\begin{array}{l}\text { Number of Listed } \\
\text { Companies }\end{array}$ & $\begin{array}{l}\text { Capitalization } \\
\text { (HKD Billions) }\end{array}$ & $\begin{array}{l}\text { Average Daily Turnover } \\
\text { (HKD Millions) }\end{array}$ \\
\hline $\mathbf{1 9 9 1}$ & 357 & 949.2 & 1,347 \\
$\mathbf{1 9 9 2}$ & 413 & $1,332.2$ & 2,802 \\
$\mathbf{1 9 9 3}$ & 477 & $2,975.4$ & 4,910 \\
$\mathbf{1 9 9 4}$ & 529 & $2,085.2$ & 4,586 \\
\hline
\end{tabular}

\footnotetext{
${ }^{5}$ Hong Kong Trade and Development Council, "Hong Kong as a Trading Hub: Entrepot and Beyond", online: <http://info.hktdc.com/econforum/hsb/hsb070401.htm>.
} 


\begin{tabular}{|l|lll|}
$\mathbf{1 9 9 5}$ & 542 & $2,348.3$ & 3,347 \\
\hline $\mathbf{1 9 9 6}$ & 583 & $3,476.0$ & 5,672 \\
$\mathbf{1 9 9 7}$ & 658 & $3,202.3$ & 15,265 \\
\hline $\mathbf{1 9 9 8}$ & 680 & $2,661.7$ & 6,887 \\
$\mathbf{1 9 9 9}$ & 708 & $4,734.7$ & 7,901 \\
\hline $\mathbf{2 0 0 0}$ & 790 & $4,862.5$ & 12,679 \\
\hline $\mathbf{2 0 0 1}$ & 867 & $3,946.3$ & 8,187 \\
\hline $\mathbf{2 0 0 2}$ & 978 & $3,611.3$ & 6,652 \\
\hline $\mathbf{2 0 0 3}$ & 1,037 & $5,547.9$ & 10,419 \\
\hline $\mathbf{2 0 0 4}$ & 1,096 & $6,695.9$ & 15,960 \\
\hline $\mathbf{2 0 0 5}$ & 1,135 & $8,179.9$ & 18,301 \\
\hline $\mathbf{2 0 0 6}$ & 1,173 & $13,337.7$ & 33,912 \\
\hline $\mathbf{2 0 0 7}$ & 1,241 & $20,697.6$ & 88,084 \\
\hline $\mathbf{2 0 0 8}$ & 1,261 & $10,298.8$ & 72,053 \\
\hline $\mathbf{2 0 0 9}$ & 1,319 & $17,874.3$ & 62,319 \\
\hline $\mathbf{2 0 1 0}$ & 1,413 & $21,077.0$ & 69,117 \\
\hline
\end{tabular}

Source: Securities and Futures Commission (SFC).

After the financial turmoil in 2008, worries over an economic slowdown also wiped across the world. For example, the Dow, Nasdaq and FTSE100 tumbled $33.8 \%, 40.5 \%$ and $31.3 \%$, respectively. Similarly, Hong Kong was not immune. The Hang Seng Index tumbled $48.3 \%$, posting the biggest drop since 1974. Yet, the continual strength of investor appetite for IPOs in Hong Kong remains. Owing to the influx of Chinese companies, Hong Kong was the champion in IPOs in 2009 and 2010 (Wall Street Journal, 2009; Financial Times, 2011), dwarfing London and New York (see Figure 2). 
Figure 2 - New Listings (USD bn) in Hong Kong, New York and London

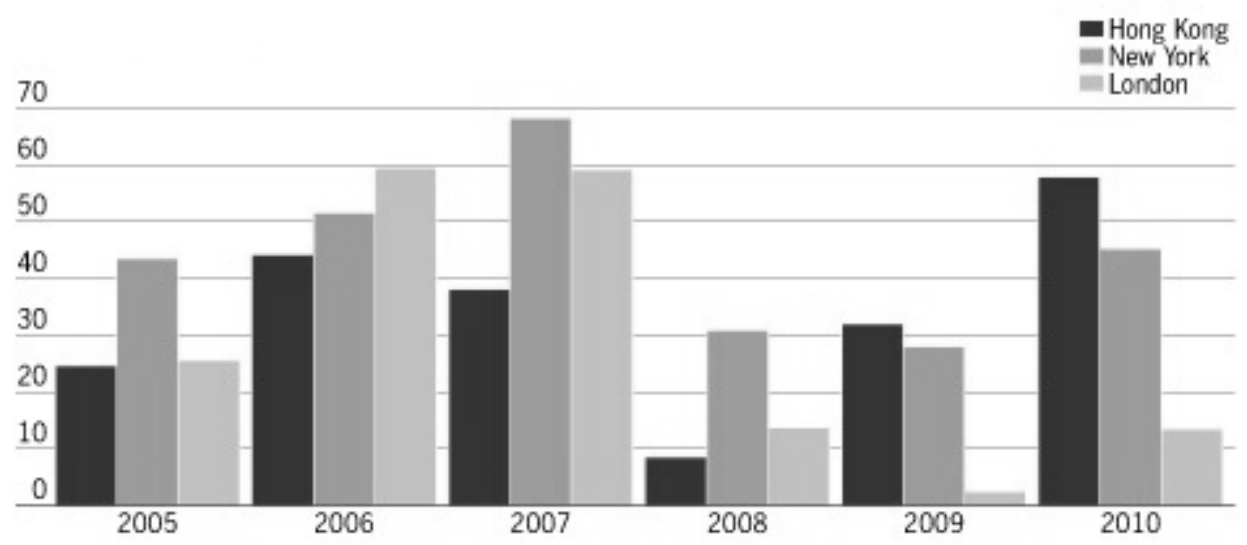

Source: Financial Times (2011).

\section{Legal System Inherited from England}

The development of Hong Kong's corporate and financial law regime has a close connection with its historical status as a colony of the British Empire. The genesis of the current framework is the Companies Ordinance of 1865 that has mirrored the English Companies Act of 1862, which incorporated both the Joint Stock Companies Registration and Regulation Act of 1844 and the Limited Liability Act of 1855 (Gu, 2006: 9). Likewise, the Companies Act 1908 in UK was followed by the Companies Ordinance 1911 in Hong Kong. The Companies Ordinance (CO) was designated as Chapter (Cap) 32 in 1933 and no significant legislative initiative in company law was introduced until 1984, which reflected the Companies Act $1948 .{ }^{6}$ Since then, the law has constantly been revised over time. ${ }^{7}$ Regarding securities law, in response to the market collapse in 1974, the Securities Ordinance and the Protection of Investors Ordinance became effective from 1 March 1974. In 1991, the Securities (Disclosure of Interests) Ordinance and Securities (Insider Dealing) Ordinance came into force. In 2003, the Securities and Futures Ordinance (SFO) consolidated and modernized all these previous ordinances regulating the securities and futures markets in Hong Kong. ${ }^{8}$ Other related rules and regulations include the Listing Rules of the Hong Kong

\footnotetext{
${ }^{6}$ The Companies Law Revision Committee was established in the early 1960s to review the company law in Hong Kong. It was subsequently replaced by the Standing Committee on Company Reform, which started the drafting work of the Companies (Amendment) Ordinance 1984 (Farrar, 2002: 474).

${ }^{7}$ Recent important amendments included the Companies (Amendment) Ordinance in 1991, 1994, 2003 and 2004.

${ }^{8}$ SFO (Cap 571).
} 
Stock Exchange, as well as the Code on Corporate Governance Practices and the Code on Takeovers and Mergers. ${ }^{9}$

One of the functions performed by law is the clear allocation and protection of property rights. Attention is particularly paid to shareholder rights as an indicator of investor protection in the articles on law and finance of La Porta et al. Voting rights attached to shares, rights that support the voting mechanism against interference by the insiders and remedial/anti-director rights in different countries were investigated. Kraakman et al. (2009a, b), similarly, view appointment rights and decision rights as governance strategies to the agency problem. However, shareholders often lack the incentive to exercise their rights, especially in a dispersed ownership setting. In a typical situation, even for larger enterprises, a few shareholders own a relatively large fraction of the company's equity. ${ }^{10}$ They must be prepared to place a considerable proportion of their wealth at risks. Therefore, they will have the incentive as well as sufficiently large shareholding interests to influence the management. However, for a more diffuse structure, an active shareholder cannot capture all the gain from becoming involved, studying the company or sitting on the board of directors. This is a collective action problem. As stressed by Roe (1996: 5), this caused most fragmented shareholders to rationally forgo involvement. Therefore, disgruntled shareholders typically adopted the so-called Wall Street rule. It is easier to switch their investment than to fight.

The substantive legal framework in Hong Kong to protect investors and to promote market efficiency is roughly similar to that of the UK under the influence from the Anglo-Saxon model during the colonial era before 1997. The regulatory framework in Hong Kong is derived primarily from three sources: (1) common law and equity ${ }^{11}$; (2) statutory legislation ${ }^{12}$; and (3) soft laws ${ }^{13}$. The Basic Law of

\footnotetext{
${ }^{9}$ The Corporate Governance Code is essentially based on the Combined Code of the UK, see Conroy (2004). Hong Kong similarly has adopted a "comply or explain" principle. Issuers are expected to comply with, but may choose to deviate from, the code provisions. The recommended best practices are for guidance only. However, they must state whether they have complied with the code provisions set out in this Code in their interim reports and annual reports. See Appendix 14 of the Listing Rules of HKEx. Likewise, Hong Kong's system addressing issues arising from takeovers and mergers is largely based on the UK system. The Code on Takeovers and Mergers is a non-statutory set of rules regulating all aspects of these sorts of activities. At the heart of the whole system, similar to the UK is the mandatory offer requirement and a "no frustration" rule. See Rules 4 and 26 of the Code.

${ }^{10}$ See La Porta et al. (1999a). This research suggested that not only in many countries large corporations have large shareholders but also that these shareholders are active in corporate governance. The degree of shareholder concentration, for example, in continental Europe is extraordinary high relative to the US and the UK, see Becht (1999).

${ }^{11}$ This, for example, is concerned with the fiduciary duties of directors.

12 This includes the $\mathrm{CO}$ and the SFO.

${ }^{13}$ This includes the Listing Rules, the Takeover Code and others.
} 
Hong Kong states that the laws previously in force in Hong Kong, which include, the common law, rules of equity, ordinances, subordinate legislation and customary law shall be maintained. ${ }^{14}$ For example, both the common law and statute impose on company directors certain duties to the company. Directors owe fiduciary duties to the company, which are based upon showing the utmost good faith. ${ }^{15}$ They must not put themselves in a position where his personal interest conflicts with that of the company. ${ }^{16}$ To reduce the likelihood of self-dealing by the directors, the Companies Ordinance provides that any director of a company who is in any way, directly or indirectly, interested in a contract with the company shall declare the nature of interest. ${ }^{17}$ The Listing Rules prescribe the timely disclosure requirements for notifiable transactions and connected transactions. ${ }^{18}$ Other general disclosure duties include the requirement for company to keep proper books of account and a report by directors dealing with the state of affairs of the company. ${ }^{19}$ The reporting obligations of majority shareholders and company officers are also specified under the SFO. ${ }^{20}$ To combat financial market crimes, there are six types of market misconduct specified: insider dealing; false trading; price rigging; disclosure of information about prohibited transactions; disclosure of false and misleading transactions; disclosure of false and misleading information; and stock market manipulation. ${ }^{21}$ Again, the terminology and definition employed are generally similar to those contained in the Financial Services and Markets Act (FSMA) 2000 of the UK. ${ }^{22}$

In the light of enforcement of rights, similar to the statutory protection of minority in England, any member of the company can apply to the court for an order under Section 168A of the Companies Ordinance on the ground that the affairs of the company are being or have been conducted in a manner unfairly prejudicial to the interests of the members. ${ }^{23}$ Of course, this may not be useful in a

\footnotetext{
${ }^{14}$ Art 8 of the Basic Law of Hong Kong. The Basic Law serves as the constitutional document of Hong Kong after the handover of sovereignty in 1997 from the UK to China.

${ }^{15}$ See for example, Re Smith \& Fawcett Ltd [1942] Ch 304 CA.

${ }^{16}$ See for example, Aberdeen Railway Co. v. Blaikie Bros (1854) 1 Macq $461 \mathrm{HI}$.

${ }^{17} \mathrm{CO}$ (Cap 32) s 162(3).

${ }^{18}$ Chapter 14 and 14A of the Listing Rules of Hong Kong ('HKLR').

${ }^{19}$ Co (Cap 32) ss 121 and 129. The directors' report includes the following information with respect to the relevant financial year: (a) the principal activities of the company; (b) the names of the persons who were directors; (c) significant changes in assets; (d) directors' material interest in a company contract; and many others.

${ }^{20}$ Part XV of the SFO (Cap 571).

${ }^{21}$ Part XIII and XIV of the SFO (Cap 571).

${ }^{22}$ See s 118 of FSMA 2000 and the Market Abuse Directive. Market abuse, a terminology used in both the UK and the EU context, consists primarily of insider information and market manipulation.

${ }^{23} \mathrm{CO}$ (Cap 32) s 168A. See also the Companies Act ('CA') 2006 of the UK s 994 (formerly CA 1985 s 459$)$.
} 
public company situation where shareholders may choose to sell their shares via the market. Even earlier than the UK, Hong Kong has put derivative action on a statutory footing in 2004 with a view to strengthening the position of minority shareholders. ${ }^{24}$ Under this mechanism, a shareholder may bring legal proceedings on behalf of the company against any director in respect of misfeasance committed against the company. This can be regarded as another statutory exception to the rule in Foss $v$. Harbottle. ${ }^{25}$ In relation to securities market crimes, all six forms of market misconduct are subjected to civil remedies and wrongdoers may be punishable as a criminal offence. ${ }^{26}$ Under the SFO, investors have a right of action in civil proceedings for their pecuniary loss as a result of another person's contravention of market misconduct provisions. ${ }^{27}$

In spite of all these, private enforcement of shareholder rights has never been a major landscape in corporate governance under the Anglo-Saxon system (Armour et al., 2009b). Similarly, these proceedings have not been frequently seen in Hong Kong. In his investigation of minority shareholder protection in Hong Kong, Lawton (2007) has identified over 200 relevant cases in 1980 to 1995. Among which, most of the cases were actions for just and equitable winding up under Section 177(1)(f) of the Companies Ordinance. There were a considerable number of the statutory minority shareholder actions under Section 168A of the Companies Ordinance in the period, but the number of derivative actions was almost negligible. ${ }^{28}$ Clearly, these cases were primarily related to small and private companies and therefore should have little impact to the securities market. Tyler and Ho (2004: 32) have attributed the lack of some representative cases of minority shareholder action in Hong Kong to the Chinese disinclination for litigation and the family structure of Hong Kong companies. The latter is to be further addressed later. Nevertheless, it is incorrect to state that the law has never been enforced. For example, a recent case in Hong Kong, Waddington Limited v. Chan Chun Hoo Thomas, contributed to the development of the concept of multiple derivative actions. ${ }^{29}$ Also, the active role of institutional investors is

\footnotetext{
${ }^{24} \mathrm{CO}$ (Cap 32) s 168BA. It was added to the ordinance by the Companies (Amendment) Ordinance 2004.

${ }^{25}$ See Foss $v$. Harbottle (1843) 2 Hare 461.

${ }^{26}$ See Part XIII of the SFO (Cap 571) for civil liability and Part XIV for criminal liability. In the civil route, the standard of proof is "on the balance of probabilities". The criminal route is likely to be used when the government considers it has sufficient evidence to prove that a person is guilty of market misconduct "beyond all reasonable doubt".

27 SFO (Cap 571) s 281.

${ }^{28}$ See Lawton (2007). The number of CO (Cap 32) s 177 actions, s 168A actions and a mixture of both was 135, 24 and 116, respectively. There were only a very small number of cases pleaded as derivative actions.

${ }^{29}$ Waddington Ltd v. Chan Chun Hoo Thomas and others [2008] (FACV 15/2007). See also Goo (2010).
} 
contemplated as one of the solutions to corporate governance problems in the Anglo-Saxon model. Likewise, the significance of overseas institutional investors in Hong Kong has clearly been rising. Their trading rose from approximately $25 \%$ of the market turnover in early 1990s to approximately $40 \%$ in recent years (Securities and Futures Commission, 2004a). In certain cases, they have duly played their role in corporate governance. ${ }^{30}$

\section{American Style of Public Enforcement}

La Porta et al. (2006) have argued that optimal regulatory arrangements can be distilled down to three broad hypotheses. The very liberal approach implies that the optimal government policy is to leave securities markets unregulated because the market and some general legal mechanisms suffice for the markets to prosper. ${ }^{31}$ A less liberal approach suggests law is necessary due to the consideration of enforcement costs and opportunistic behavior of market players. Ultimately, governmental intervention may be desirable when all existing markets, legal mechanisms and private enforcement incentives are deemed insufficient. Therefore, a public enforcer is needed to support trade. Public enforcement may work because the enforcer is independent and focused.

Different jurisdictions have adopted different regulatory models to regulate the market. For example, comparing both sides of the Atlantic, the Securities and Exchange Commission (SEC) in the US has taken a more active role in policing the market than the Financial Services Authority (FSA) in the UK. Gadinis and Jackson (2007) have tried to categorize different jurisdictions into three distinct models. The Continental model (France, Germany and Japan), which is described as the government-led model, preserves significant authority for central government control over securities markets regulation, although with a relatively limited enforcement apparatus. The American model (cooperation model) assigns a broad range of power to market participants in almost all aspects of securities regulation but also maintains strong and overlapping oversight of

\footnotetext{
${ }^{30}$ For example, in April 2007, the Hong Kong-listed arm of China National Offshore Oil Corporation (CNOOC) voted $52 \%$ to $48 \%$ to stop the Chinese oil company from continuing to deposit funds with its state-controlled parent. The practice is widespread among many Hong Kong listed subsidiaries of state-controlled Chinese companies and has attracted growing criticism from investors concerning that the parent company could run off with the money. CNOOC lost the vote following a campaign led by Institutional Shareholder Services, the US based advisory group. See Financial Times (2007).

${ }^{31}$ This theory is advocated by the Chicago school of economists like Ronald Coase. In this situation, issuers of securities have an incentive to disclose all available information to obtain higher prices simply because the failure to disclose would cause investors to assume the worst. Furthermore, auditors and underwriters can credibly certify the quality of securities to safeguard their reputation.
} 
market activity through well-endowed governmental agencies with more robust enforcement traditions. The English model (flexibility model) grants significant leeway to market participants in performing their regulatory obligations, but relies on government agencies to set general policies and maintain some enforcement capacity.

\section{A. Paradigm Shift from "Positive Non-interventionism" to "Proactive Market Enabling”}

The political explanation to the growth of Western securities markets as given by Roe (2005: 199) is, if a society's institutions do not promote shareholder value, then ownership separation, which can influence the depth of a market, ought to be narrower than elsewhere. Friedman (1997) has once referred to Hong Kong as the example of capitalism in action. ${ }^{32}$ Indeed, he further suggested that the success of laissez-faire capitalist policy in Hong Kong was a major factor in encouraging China and other countries to move away from centralized control towards greater reliance on private enterprises and the free market (Friedman, 2006). ${ }^{33}$ According to the recent Index of Economic Freedom, Hong Kong ranks the first among 157 countries. ${ }^{34}$ This illustrates the success of the "positive non-interventionism" policy implemented by the government since the British rule amid concerns that Hong Kong has been becoming more interventionist and more susceptible to political influence from China after the handover in 1997. In contrast to the Continental system with strong labor institutions, Hong Kong has always tried to foster a flexible and competitive private sector, and to retain its small government posture (Goodhart \& Dai, 2003: 15). Economists have stressed the idea that good economic institutions, especially those in the public sector, are instrumental to economic growth. Non-interventionism is arguably considered as one aspect of good government (La Porta et al., 1999b: 225). Self-regulation has been an important feature of the English model. In relation to a wide variety of types of activities, market participants have established, of their own accord, industrial, professional and social organizations to oversee and regulate matters of common interest (Cheffins, 1997). The financial market regulation in Hong Kong had originally been based on self-regulation by the exchange until 1987.

\footnotetext{
${ }^{32} \mathrm{He}$ said the postwar economic fortunes of Hong Kong, Great Britain and Israel formed a nice controlled experiment that demonstrated the superiority of market economies. Britain went for socialism and Hong Kong went for laissez-faire free markets.

${ }^{33}$ He highly praised the "positive-non-interventionism" policy implemented by former Financial Secretary, John Cowperthwaite in the 1960s.

${ }^{34}$ The Heritage Foundation, "Index of Economic Freedom", online:

$<$ http://www.heritage.org/index/ranking >.
} 
In fact, the crash in 1974 had already attracted government attention and led to the introduction of legislation in the form of the Securities Ordinance, which was administered by the Securities Commission. This required the registration of all stockbrokers, dealers, and investment advisers. However, in the view of Gunningham (1990: 20), the government regulation of the stock market at this point was more apparent than real. First, the government was still committed to laissez-faire and non-intervention. Second, the regulator was in fact starved of resources by the colonial government which had little understanding of the complexities of financial market regulation. As a result, the role of the Securities Commission took a passive and reactive role instead of actively monitoring markets and brokers. Not until 1987 when the world's securities markets braced themselves for another crash, the Hong Kong government started to realize the need to strengthen its systems and regulatory arrangements to maintain its position as the primary capital market for the Asian region. The crash of 1987 led to the appointment of the Securities Review Committee on 16 November 1987 by then Governor, Sir David Wilson. The Committee, chaired by Ian Hay Davison was asked to review the constitution, powers, management and operation of the stock exchange and its regulatory body. The Report of the Securities Review Committee ("Davison Report") recommended major reforms, including the establishment of a single independent statutory body to regulate and supervise the securities and futures industry.

The Securities and Futures Commission Ordinance, which passed its final reading in 1989 after the publication of the Davison Report, marked the beginning of a strong single regulator. Former Financial Secretary, Anthony Leung declared himself a believer in the free market but at the same time said in 2002 that "proactive market enabling" should probably be a more appropriate and accurate way to describe what a government should do (Hong Kong Government, 2002). Consistent with this paradigm shift, Jackson and Roe (2009) have alleged that Hong Kong has one of the most intense securities regulators in the world. Hong Kong had the highest adjusted staffing and budgets in 2006 among all other markets. ${ }^{35}$ In the financial year of 2009/2010, the Securities and Futures Commission in Hong Kong continued to increase its budget to HKD730 million

\footnotetext{
${ }^{35}$ See Jackson and Roe (2009). The direct staff per million of population ratio in Hong Kong was 58.47. The figure of the US was 23.29, a place where the enforcement intensity has been high. In relation to the budgets, Hong Kong had a budget of around USD365,000 per billion GDP whereas in the UK and US, the figures were around USD65,000 and USD76,000, respectively. But note that due to Hong Kong's small absolute size (both in GDP and population), the results may be flattered in these comparisons. For example in 2008, there were around 3,600 staff in the SEC and the number of listed companies in the US at that time was 5,600. Meanwhile, there were around 450 staff in the SFC and the number of listed companies in Hong Kong was 1,250. The listed companies to staff ratio in the US was better than that in Hong Kong in this case. Figures for 2008 are taken from the World Federation of Exchanges and respective exchanges.
} 
(see Table 2). All these, to a large extent, illustrate the disproportionately large role of the financial market in Hong Kong. The government is committed to preserving the integrity and the efficiency of the market. Although this may reflect an ex ante threat of sanction, on an ex post basis, the threat is equally high.

\section{Table 2 - Comparative Number of Staff and Expenditure of Selected Jurisdictions}

\begin{tabular}{lccr} 
& $\mathbf{2 0 0 9 - 1 0}$ & $\mathbf{2 0 0 8 - 0 9}$ & $\mathbf{2 0 0 7 - 0 8}$ \\
\hline SFC (year ended on 31 March) & 501 & 478 & 442 \\
Number of staff & 730 & 684 & 585 \\
Total expenditure (\$ million) & & & \\
\hline US Securities and Exchange Commission (SEC) (year ended on 30 September) & 3,816 & 3,656 & 3,511 \\
Number of staff & 8,689 & 7,441 & 7,046 \\
Total expenditure (\$ million) & & & \\
\hline UK Financial Services Authority (FSA) (year ended on 31 March) & 2,800 & 2,730 & 2,535 \\
Number of staff (at year-end date) & 5,207 & 3,999 & 5,026
\end{tabular}

Source: Securities and Futures Commission (SFC).

While the US and UK often had more than 500 and 100 enforcement cases brought by the national regulators per year, respectively, Hong Kong's annual average of over 100 actions has been high considering that the Hong Kong market is smaller than the US and the scope of regulation of the SFC is narrower than the FSA (Coffee, 2007). ${ }^{36}$ Furthermore, the SFC does not hesitate to initiate criminal prosecutions against market abusers and take them to court. The first criminal conviction for insider dealing was seen in 2008 after insider dealing had been made a criminal offence under the SFO in $2003 .{ }^{37}$ A more recent case has even attracted worldwide media coverage. ${ }^{38}$ A former investment banker for BNP Paribas was found guilty of insider trading and expected to become the first jailbird in Hong Kong for insider trading (Financial Times, 2009b). In 2008-2009, Hong Kong's SFC initiated ten prosecutions for insider trading, resulting in ten guilty verdicts, dozens of convictions and five jail sentences (Economist, 2009). A change in regulatory approach has come as a shock to many. Hong Kong is

\footnotetext{
${ }^{36}$ The figures of Hong Kong were compiled from the annual reports of the SFC. In 2006-2007, there were 51 criminal prosecutions, 80 administrative actions and 4 cases referred to the Market Misconduct Tribunal. In 2007-2008, there were 72 administrative actions. Also, 74 entities were charged in criminal proceedings and 9 civil cases commenced. The FSA has been given statutory powers to regulate the financial services in the UK including deposit taking, insurance, mortgage lending, general insurance advice, mortgage advice and investment business. But the SFC is responsible for regulating the securities and futures markets only.

${ }^{37}$ The offender was sentenced to six months imprisonment, suspended for two years. She was also fined HKD200,000 and ordered to reimburse the costs incurred by the SFC. See Securities and Futures Commission (2008).

${ }^{38}$ Incidentally, the first insider dealing criminal prosecution in the UK brought by the Financial Services Authority took place at around the same time, see Financial Services Authority (2009).
} 
gradually turning itself into a scourge for insider trading. In their survey of securities laws in 49 countries, La Porta et al. (2006) have given Hong Kong full marks in ten aspects out of twelve regarding public enforcement. This certainly confirms how well Hong Kong has performed in the field.

\section{Chinese Way of Doing Business}

The Western concept of separate legal personality can play a role in safeguarding minority shareholder's interests because there is a real separation between family/state and company. There is an impersonal pattern of possession in the UK, the US, Australia, Canada and New Zealand (Lawton, 1996: 27-28). However, Chinese companies, for example, show different characteristics. As opposed to the separation of ownership and control, professionalization, bureaucratization and neutralization, they retain characteristics of small-scale family businesses such as paternalism, personalism, opportunism and flexibility, even when conducting a very large scale of operations (Lawton, 1996: 27-28). ${ }^{39}$ Private benefits of control are therefore much higher. The rise of dispersed ownership, which has been a result induced by strong shareholder protection or other functional substitutes, is arguably associated with the development of a stock market (Cheffins, 2001; Coffee, 2001; Roe, 2006). ${ }^{40}$ Apart from the perception that Hong Kong is an international business center heavily influenced by the Anglo-American model of separation of management and ownership, most listed companies in Hong Kong have been controlled by families.

Chen et al. (2005) have analyzed a sample of 412 publicly listed Hong Kong companies during 1995 to 1998 and found that the majority of them were closely held: $61.1 \%$ had a family controlling at least $30 \%$ of voting rights. Data from the survey of La Porta et al. (1999a) on corporate ownership around the world is even more revealing. Using $20 \%$ as the criterion for control, $70 \%$ of the large publicly traded companies in Hong Kong were family controlled, the highest percentage among other 27 wealthy economies in the sample (La Porta et al., 1999a: 492). As a general observation, Claessens et al. (2000) have indicated that corporations in Hong Kong are predominantly controlled by families. While both Ho (2004: 383-388) and Lawton (1996) agree that family-controlled companies can make efficient decisions due to more personalistic methods of control with less paperwork and fewer formalities, there are inherent conflicts between the controlling and minority shareholders of companies. The former have high incentives to extract private benefits through their control in connected party transactions. Ho (2004: 386-387) has observed that common forms of

\footnotetext{
${ }^{39}$ In the Chinese context, personal connections or guanxi have remained a key element of Chinese organization.

40 There is an apparent interaction between the three spheres: law, ownership and market.
} 
misbehavior among controlling shareholders in Hong Kong include: unfair terms for intra-group sales of goods and services, the transfer of assets and controlling stakes at the expense of minority shareholders, directing corporate resources to themselves and others. The predominance of family ownership and control of companies in Hong Kong is rather incompatible with the rise of it as an international financial center if one believes in the nexus between shareholder protection and market growth. The only explanation in this case appears to be the gain in efficiency has outweighed the increase in agency costs. In the aftermath of the credit crisis, it can be argued that by retaining family control, Asia's most successful entrepreneurs are able to take a long-term view (Financial Times, 2009c).

\section{A. Extending the Family Ties to the Nation as a Whole}

The increasing economic prominence of China is clearly reshaping the international financial system. It has grown strongly over the past decade with averaged GDP growth at $9.1 \%$ and projections suggest this trend may continue (Winters \& Yusuf, 2007). ${ }^{41}$ Commentators allege that China could continue to make a big leap by strengthening the links with Hong Kong and transferring financial know-how from the former British colony (Financial Times, 2009a). Indeed, it is a mutually beneficial scenario. The Hong Kong stock market used to be dependent on the property sector, but now has a more diversified structure due to the increasing presence of Chinese companies which consist of companies from a variety of sectors. The property sector accounted for $31 \%$ of the total market capitalization at the end of 1996, declining to $11 \%$ in 2004 (Securities and Futures Commission, 2004b). However, the finance sector rose from $23.2 \%$ to $37 \%$ in the same period as a result of the growth of HSBC, the Standard Chartered Bank and the admission of Chinese banks to listing. Meanwhile, the Chinese companies now have an overwhelmingly important presence in the stock exchange. Indeed, for China, the Hong Kong market has been as equally important as the domestic market in terms of fundraising (see Table 3).

\footnotetext{
${ }^{41}$ At one point, China accounted for only $5 \%$ of world gross domestic product, but it had a quarter of world population.
} 
Yeung and Huang: Law and Finance: What Matters? Hong Kong as a Test Case

Table 3 - Yearly Total Funds Raised Domestically and in Hong Kong through IPOs

\begin{tabular}{|c|c|c|c|c|c|c|c|c|}
\hline \multicolumn{2}{|c|}{ H-Share } & \multicolumn{2}{c|}{ Red-Chip } & \multicolumn{2}{c|}{ A-Share } & Total Funds & \begin{tabular}{c} 
\% of \\
Funds \\
\cline { 2 - 9 }
\end{tabular} \\
\cline { 2 - 10 } & $\begin{array}{c}\text { No. of } \\
\text { New Listings }\end{array}$ & USD Bn & $\begin{array}{c}\text { No. of } \\
\text { New Listings }\end{array}$ & USD Bn & $\begin{array}{c}\text { No. of } \\
\text { New Listings }\end{array}$ & USD Bn & $\begin{array}{c}\text { Raised (USD } \\
\text { Bn) }\end{array}$ & $\begin{array}{c}\text { Raised in } \\
\text { HK }\end{array}$ \\
\hline 1993 & 6 & 1.90 & 20 & 0.22 & 130 & 4.80 & 6.92 & $\mathbf{3 0 . 6 5}$ \\
\hline 1994 & 9 & 1.03 & 9 & 0.16 & 108 & 1.16 & 2.35 & $\mathbf{5 0 . 6 4}$ \\
\hline 1995 & 2 & 0.22 & 2 & 0.17 & 32 & 1.02 & 1.42 & $\mathbf{2 7 . 9 5}$ \\
\hline 1996 & 6 & 0.76 & 5 & 0.38 & 207 & 3.54 & 4.69 & $\mathbf{2 4 . 4 9}$ \\
\hline 1997 & 16 & 3.61 & 14 & 4.44 & 215 & 9.96 & 18.01 & $\mathbf{4 4 . 6 8}$ \\
\hline 1998 & 2 & 0.23 & 4 & 0.02 & 106 & 9.40 & 9.65 & $\mathbf{2 . 5 9}$ \\
\hline 1999 & 3 & 0.48 & 5 & 0.27 & 98 & 10.79 & 11.55 & $\mathbf{6 . 5 2}$ \\
\hline 2000 & 6 & 6.03 & 2 & 5.02 & 139 & 18.45 & 29.50 & $\mathbf{3 7 . 4 7}$ \\
\hline 2001 & 8 & 0.80 & 3 & 1.36 & 72 & 14.28 & 16.45 & $\mathbf{1 3 . 1 8}$ \\
\hline 2002 & 16 & 2.18 & 2 & 2.37 & 64 & 9.42 & 13.97 & $\mathbf{3 2 . 5 6}$ \\
\hline 2003 & 18 & 5.58 & 2 & 0.34 & 63 & 9.90 & 15.82 & $\mathbf{3 7 . 4 2}$ \\
\hline 2004 & 17 & 4.81 & 5 & 1.65 & 90 & 10.10 & 16.56 & $\mathbf{3 9 . 0 5}$ \\
\hline 2005 & 12 & 16.01 & 4 & 0.12 & 4 & 4.13 & 20.26 & $\mathbf{7 9 . 6 2}$ \\
\hline 2006 & 23 & 36.03 & 2 & 0.34 & 53 & 30.91 & 67.27 & $\mathbf{5 4 . 0 6}$ \\
\hline 2007 & 9 & 10.40 & 7 & 6.69 & 116 & 101.56 & 118.65 & $\mathbf{1 4 . 4 0}$ \\
\hline 2008 & 7 & 5.39 & 0 & 0.00 & 75 & 14.89 & 20.28 & $\mathbf{2 6 . 5 7}$ \\
\hline 2009 & 3 & 5.87 & 1 & 1.13 & 57 & 32.74 & 39.74 & $\mathbf{1 7 . 6 2}$ \\
\hline
\end{tabular}

Source: HKEx, National Bureau of Statistics of China and the China Securities Regulatory Commission.

Note: H-share companies refer to those China-incorporated companies, which are listed in Hong Kong. By contrast, Red-chips refer to those Hong Kong-listed Chinese companies, which are incorporated in jurisdictions outside China such as Bermuda and the Cayman Islands. Meanwhile, A-share companies are incorporated and listed domestically.

Hong Kong recently became the largest IPO fundraising center, surpassing the New York and London Stock Exchanges, and handled the listing of megasized IPOs such as Agricultural Bank of China and Industrial and Commercial Bank of China, with the two being the world's largest ever IPO at that time. In 2008, there were 465 Chinese companies (in a very broad sense) listed in the Hong Kong market and their capitalization accounted for $60 \%$ of the Hong Kong Stock Exchange's total market capitalization (Hong Kong Government, 2009: 67). ${ }^{42}$ Equity funds raised by these Chinese companies in that year amounted to HKD281 billion, which was $71 \%$ of the total equity funds raised through the exchange during the year. Without doubt, recent IPO activities have been hampered by the global financial turmoil. In 2008, 29 IPOs were launched. This was far lower than the total of 80 IPOs in 2007. The total fund raised was HKD66

\footnotetext{
${ }^{42}$ Here, Chinese companies refer to those incorporated in China under the Chinese Company Law as well as those incorporated outside China but with actual business based in China and controlled by Chinese shareholders.
} 
billion, 77\% lower than the HKD292.4 billion raised in 2007. Such sluggish performance appears to be inevitable amid a worsening economic climate. One of the good news was, in September 2008, China banned all domestic IPO activities for nine months (Caijing Magazine, 2009). This drove many prospective issuers to Hong Kong. In the first half of 2009, there were ten IPOs in Hong Kong with HKD12.4 billion raised. These figures were pathetic when comparing with a few years before, but the IPO market in Hong Kong is enviable during a difficult economic time.

Hong Kong has always been keen to attract the listing of companies from overseas jurisdictions. In fact, many companies operating and listing in Hong Kong are incorporated elsewhere. These companies include those established in China as well as offshore jurisdictions such as the Cayman Islands, Bermuda and the Cook Islands. These companies, having established places of business in Hong Kong are known as non-Hong Kong companies. ${ }^{43}$ The structure of listing rules relevant to cross-listings in Hong Kong is more complex than, for example, in London because of the presence of special rules dealing with individual jurisdictions. While the general Listing Rules of Hong Kong ("HKLR") apply to overseas issuers, Chapters 19 and 19A of the Listing Rules set out the rules applying to non-Hong Kong issuers. Many of these special rules reiterate the applicability of various Listing Rules to non-Hong Kong issuer or provide for modifications for them. Three core concerns are shareholder protection, localization requirements and accounting matters (Hsu et al., 2006: 177).

Normally, overseas issuers incorporated in the common law jurisdictions of Bermuda, the Cayman Islands and the Cook Islands may list on the HKEx provided that certain additional requirements set out or referred to in Chapter 19 are fulfilled. Issuers from China, by contrast, have presented a problematic case. First, the legal system in China is not based on a common law system. Second, existing Chinese law imposes various restrictions affecting the use of foreign exchange in China and its remittance out of the territory. Third, different markets in the shares of an issuer exist. Only Chinese citizens and legal persons are permitted to own the domestic shares of a Chinese issuer (which are denominated in $\mathrm{RMB}$ ) and only foreign investors are permitted to own the overseas listed shares (which are denominated in foreign currencies). More importantly, when the first Chinese company, Tsingtao Brewery, was listed on the HKEx on 15 July 1993, China did not have a proper set of company laws. Therefore, some specific rules and regulations have been necessary to bridge the gaps between two systems.

So far as companies incorporated in China listing and issuing shares in Hong Kong are concerned, Chapter 19A of the Listing Rules sets out the rules

\footnotetext{
${ }^{43} \mathrm{CO}$ (Cap 32) s 332. According to the investigation by Lau and MacNeil (2001: 791), in 2000, $73 \%$ of listed companies in Hong Kong were incorporated overseas. The vast majority of them were incorporated in three jurisdictions: Bermuda, the Cayman Islands and China.
} 
applying to these Chinese issuers. As with non-Hong Kong issuers generally, the HKEx will require the presence of a sufficient level of shareholder protection under Chinese laws and the constitutive documents of the issuer. In particular, the articles of association of the issuers must contain provisions which reflect the different nature of domestic shares and overseas listed foreign shares and the different rights of their respective holders. Finally, it must be provided that disputes involving holders of foreign shares and arising from the articles of association or from any applicable law or regulation are to be settled by arbitration in either Hong Kong or China at the election of the claimants. Lau and MacNeil (2001: 803-804) have rightly pointed out that the major concern in cross-listing is the difference in shareholder protection regime between locally incorporated companies and foreign companies, where one subject to strong (local) protection and the other subject to weak (overseas) protection. The general principle in Hong Kong is that all holders of listed securities should be treated fairly and equally and the directors of listed companies should act in the interests of its shareholders as a whole. ${ }^{44}$ The HKEx has especially stressed that the purpose of Rule 19A is to clarify that the Listing Rules apply to Chinese issuers as much as they do to Hong Kong and other overseas issuers.

In a nutshell, specific provisions applying to Chinese issuers can be classified into three categories. First, those are relatively neutral. They are in place in the light of the Chinese corporate system. For example, supervisors are required to exhibit the same qualities as directors. ${ }^{45}$ Also, separate voting of different class of shares (domestic and foreign) is sometimes required. ${ }^{46}$ Certainly, it can be argued that this can provide additional safeguards as consent must be sought particularly from foreign shareholders. Second, those impose a more stringent standard. This can be exemplified by a special arbitration mechanism and a longer period of notice, which must be given prior to the shareholders' general meeting. ${ }^{47}$ Third, in a very rare instance, but unfortunately important, concession is offered to Chinese issuers. They are exempt from disclosing any related party transactions associated with "Chinese governmental body", which is usually their controlling shareholder. ${ }^{48}$ On the one hand, this is understandable as the state is virtually impossible to report every related party relationship and transaction. The state simply has stakes, both directly and indirectly, in a vast number of Chinese companies. For example, in their survey of 2006, the Shanghai Stock Exchange discovered that out of 831 listed companies, 587 were state-

\footnotetext{
${ }^{44}$ HKLR 2.03

${ }^{45}$ See for example, HKLR 13.67-69, 19A.18.

${ }^{46}$ See for example, HKLR 19A.38.

${ }^{47}$ See HKLR 19A.54 and art 53 of the Mandatory Provisions for the Articles of Association of Companies to List Abroad.

${ }^{48}$ HKLR 19A. 19.
} 
owned or state-controlled enterprises (Shanghai Stock Exchange, 2006: 28). These companies together engaged in more than 20,000 related party transactions in a single year. On the other hand, the exemption has sacrificed a substantial degree of investor protection and certainty. This rings alarm bells as to whether Hong Kong has compromised its strong market image for the sake of revenues.

Chance favors the prepared mind. Hong Kong may have possessed the institutional preconditions of a strong market. Without the growth of China, there is no way it can challenge London and New York as the new international finance center. A natural linkage between industrial activity and the growth of financial market simply exists. Before an investment opportunity can appear, there must be a project with prospects first. Hong Kong, with a high degree of geopolitical proximity to China, but with essentially different legal structures and socioeconomic system, provides an excellent fundraising ground for China. This is a win-win scenario where China can obtain the capital required for economic development while Hong Kong stands to gain from listing fees and the provision of associated financial services. In fact, Hong Kong has developed a critical mass of expertise in financial services and related professional sectors. For example, Hong Kong has the fourth largest number of Chartered Financial Analysts (CFA) in the world after the US, Canada and the UK. ${ }^{49}$ The number of Certified Public Accountants grew from approximately 11,500 in 1995 to more than 25,000 in around a decade (Securities and Futures Commission, 2006). The heavy presence of these intermediaries has always been one of the strong foundations to the Hong Kong market.

\section{Conclusion}

Legal origin theorists argue that legal origins long preceded modern markets since markets could not have caused legal origin. Legal origin causes good financial law and then good financial law can make markets flourish. Roe (2006: 481) has criticized that "legal origin has become bundled in too many people's minds". Although the legal origins literature has pushed academia to think more deeply about how institutions and markets relate, legal origin alone is not able to explain the differences of the depth of market development between civil and common law countries. What really matters should be whether the system can provide the necessary ingredients to perform the job. Roe (2006: 481) has rightly pointed out that public enforcement of securities law revolving around a regulatory agency is not "an intrinsic common law institutional advantage". By utilizing the flexibility of how Chinese people conduct business, Hong Kong is miraculously able to take advantages of the successful ingredients of different systems but mitigating the

\footnotetext{
${ }^{49}$ See the most updated figures from the CFA Institute, online: <http://www.cfainstitute.org >.
} 
drawbacks. This paper is not advocating that Hong Kong is the model to follow. Otherwise, it just repeats the fallacy of the legal origin theorists that there is a generic model of success. Rather, this paper is simply a discussion of how Hong Kong can satisfy some general preconditions of a strong market on its course to an international finance center, but with an understanding that particular markets may have their own story.

\section{References}

Allen, Franklin \& Gale, Douglas, Comparing Financial Systems (London: MIT Press, 2000).

Armour, John et al., "Shareholder Protection and Stock Market Development: An Empirical Test of the Legal Origins Hypothesis" (2009a) 6 Journal of Empirical Legal Studies 343.

Armour, John et al., "Private Enforcement of Corporate Law: An Empirical Comparison of the UK and US" (2009b) 6 Journal of Empirical Legal Studies 687.

Atje, Raymond \& Jovanovic, Boyan, "Stock Markets and Development" (1993) 37 European Economic Review 632.

Becht, Marco, "Blockholdings in Europe: An International Comparison" (1999) 43 European Economic Review 1049.

Beck, Thorsten et al., "Law, Politics, and Finance" (2001) World Bank Policy Research Working Paper No. 2585, online: $<$ http://ssrn.com/abstract=269118>.

Berle, Adolf \& Means, Gardiner, The Modern Corporation and Private Property (New York: Macmillan, 1933).

Black, Bernard \& Gilson, Ronald, "Venture Capital and the Structure of Capital Markets: Banks versus Stock Markets" (1997) 47 Journal of Financial Economics 243.

Black, Bernard, "The Core Institutions that Support Strong Securities Markets" (2000) 55 Business Lawyer 1565.

Black, Bernard, "The Legal and Institutional Preconditions for Strong Securities Markets" (2001) 48 UCLA Law Review 781. 
Caijing Magazine, "The Self-restraining A-Share Market" (25 May 2009) (in Chinese).

Cassis, Youssef, Capitals of Capital (Cambridge: Cambridge University Press, 2006).

Cheffins, Brian, Company Law: Theory, Structure and Operation (Oxford: Clarendon, 1997).

Cheffins, Brian, "Does Law Matter? The Separation of Ownership and Control in the United Kingdom" (2001) 30 Journal of Legal Studies 459.

Chen, Zhilan at el., "Ownership Concentration, Firm Performance and Dividend Policy in Hong Kong” (2005) 13 Pacific-Basin Finance Journal 431.

City of London \& Z/Yen Group, "The Global Financial Centers Index” (2009), online: <http://www.cityoflondon.gov.uk/GFCI>.

Claessens, Stijin et al., "The Separation of Ownership and Control in East Asian Corporations" (2000) 58 Journal of Financial Economics 81.

Coffee, John, "The Rise of Dispersed Ownership: The Roles of Law and the State in the Separation of Ownership and Control" (2001) 111 Yale Law Journal 1.

Coffee, John, "Law and the Market: The Impact of Enforcement" (2007) 156 University of Pennsylvania Law Review 229.

Conroy, Patrick, "Corporate Governance in Hong Kong” (2004) Presentation at International Finance Corporation.

Economist, "Insider Trading in Hong Kong: To the Dungeon" (17 September 2009).

Farrar, John, "Developing Corporate Governance in Greater China" (2002) 25 UNSW Law Journal 462.

Financial Services Authority, "Solicitor and his Father-in-law Found Guilty in FSA Insider Dealing Case" (27 March 2009).

Financial Times, “On Asia: Shareholder Activism Taking Root in Asia” (13 April 2007). 
Financial Times, "Hong Kong Poses Threat to City" (6 October 2008).

Financial Times, "Amid the Economic Rubble, Shangkong will Rise" (11 May 2009a).

Financial Times, "Hong Kong Banker Guilty of Insider Trading" (12 March 2009b).

Financial Times, "Lessons for the West from Asian Capitalism” (19 March 2009c).

Financial Times, "Hopes High that Prada's IPO will Set the Style for Hong Kong" (2 February 2011).

Friedman, Milton, "The Real Lesson of Hong Kong" (1997), online: $<$ http://www.chicagogsb.edu/magazine/fall97/hongkong.html>.

Friedman, Milton, “Hong Kong Wrong” Wall Street Journal (6 October 2006).

Gadinis, Stavros \& Jackson, Howell, "Markets as Regulators: A Survey" (2007) 80 Southern California Law Review 1239.

Goo, S.H., "Multiple Derivative Action and Common Law Derivative Action Revisited: A Tale of Two Jurisdictions" (2010) 10 Journal of Corporate Law Studies 255.

Goodhart, Charles \& Dai, Lu, Intervention to Save Hong Kong (Oxford: Oxford University Press, 2003).

Gu, Minkang, Understanding Chinese Company Law (Hong Kong: Hong Kong University Press, 2006).

Gunningham, Neil, "Moving the Goalposts: Financial Market Regulation in Hong Kong and the Crash of October 1987” (1990) 15 Law \& Social Inquiry 1.

Ho, Simon, "Corporate Governance and Disclosures" in Simon Ho et al. (eds.) The Hong Kong Financial System (Oxford: Oxford University Press, 2004).

Hofsted, Geert, Cultures and Organizations (London: HarperCollins, 1994).

Hong Kong Government, "Press Release" (14 March 2002), online: <http://www.info.gov.hk/gia/general/200203/14/0314236.htm>. 
Hong Kong Government, Yearbook 2007 (Hong Kong: Hong Kong Government, 2008).

Hong Kong Government, Yearbook 2008 (Hong Kong: Hong Kong Government, 2009).

Hsu, Berry et al., Financial Markets in Hong Kong: Law and Practice (Oxford: Oxford University Press, 2006).

Jackson, Howell \& Roe, Mark, "Public and Private Enforcement of Securities Laws: Resource-Based Evidence" (2009) 93 Journal of Financial Economics 207.

Khanna, Tarun \& Palepu, Krishna, "The Evolution of Concentrated Ownership in India Broad Patterns and a History of the Indian Software Industry" (2004) NBER Working Paper No. W10613, online: $<$ http://ssrn.com/abstract=565166>.

Kraakman, Reinier et al., "Agency Problems and Legal Strategies" in Reinier Kraakman et al. (eds) The Anatomy of Corporate Law: A Comparative and Functional Approach (Oxford: Oxford University Press, 2009a).

Kraakman, Reinier et al., "The Basic Governance Structure" in Reinier Kraakman et al. (eds) The Anatomy of Corporate Law: A Comparative and Functional Approach (Oxford: Oxford University Press, 2009b).

La Porta, Rafael et al., "Legal Determinants of External Finance" (1997) 52 Journal of Finance 1131.

La Porta, Rafael et al., "Law and Finance" (1998) 106 Journal of Political Economy 1113.

La Porta, Rafael et al., "Corporate Ownership around the World" (1999a) 64 Journal of Finance 471.

La Porta, Rafael et al., "The Quality of Government” (1999b) 15 Journal of Law, Economics \& Organization 222.

La Porta, Rafael et al., "Investor Protection and Corporate Governance" (2000) 58 Journal of Financial Economics 3.

La Porta, Rafael et al., "What Works in Securities Laws?" (2006) 61 Journal of Finance 1. 
Yeung and Huang: Law and Finance: What Matters? Hong Kong as a Test Case

Lau, Alex \& MacNeil, Iain, "International Corporate Regulation: Listing Rules and Overseas Companies" (2001) 50 International \& Comparative Law Quarterly 787.

Lawton, Philip, "Berle and Means, Corporate Governance and the Chinese Family Firm” (1996) 6 Australian Journal of Corporate Law 1.

Lawton, Philip, "Modeling the Chinese Family Firm and Minority Shareholder Protection: The Hong Kong Experience 1980-1995" (2007) 49 Managerial Law 249.

Levine, Ross, "Bank-Based or Market-Based Financial Systems: Which is Better?" (2002) NBER Working Paper No. 9138, online: $<$ http://www.nber.org/papers/w9138>.

Levine, Ross \& Zervos, Sara, "Stock Market Development and Long-Run Growth" (1996) 10 World Bank Economic Review 323.

Michie, Ranald, The Global Securities Market (Oxford: Oxford University Press, 2006).

Pistor, Katharina et al., "Economic Development, Legality, and the Transplant Effect" (2003) 47 European Economic Review 165.

Roe, Mark, Strong Managers Weak Owners: The Political Roots of American Corporate Finance (Princeton, NJ: Princeton University Press, 1996).

Roe, Mark, Political Determinant of Corporate Governance (Oxford: Oxford University Press, 2003).

Roe, Mark, Corporate Governance: Political and Legal Perspectives (Cheltenham: Edward Elgar, 2005).

Roe, Mark, "Legal Origins, Politics and Modern Stock Markets" (2006) 120 Harvard Law Review 460.

Securities and Futures Commission, Securities Regulation in Hong Kong (Hong Kong: Securities and Futures Commission, 2002).

Securities and Futures Commission, "Understanding Investors in the Hong Kong Listed Securities and Derivatives Markets" (2004a), online: $<$ http://www.sfc.hk/sfc/html/EN/research/research/research.html>. 
Securities and Futures Commission, "The Listing of Mainland Companies on HKEx and the Implications for Hong Kong" (2004b), online: $<$ http://www.sfc.hk/sfc/html/EN/research/research/research.html>.

Securities and Futures Commission, "Hong Kong as a Leading Financial Centre in Asia" (2006), online:

<http://www.sfc.hk/sfc/html/EN/research/research/research.html>.

Securities and Futures Commission, "Enforcement Reporter" (2008).

Shanghai Stock Exchange, Corporate Governance Report 2006 (Shanghai, Fudan University Press, 2006)

Siems, Mathias, "Comparative Law - Do We Need Statistical Evidence in Law in Order to Reduce Complexity?" (2005) 13 Cardozo Journal of International \& Comparative Law 521.

Siems, Mathias, "Legal Origins: Reconciling Law \& Finance and Comparative Law" (2007) 52 McGill Law Review 55.

Spamann, Holger, “On the Insignificance and/or Endogeneity of La Porta et al.'s 'Anti-Director Rights Index' under Consistent Coding” (2006) Harvard Law School John M. Olin Center Discussion Paper No. 7, online: $<\mathrm{http}: / /$ ssrn.com/abstract=894301>.

Tao, Zhigang \& Wong, Richard, "Hong Kong: From an Industrialized City to a Centre of Manufacturing-related Services" (2002) 39 Urban Studies 2345.

Time Magazine, “A Tale of Three Cities” (17 January 2008).

Tyler, Edward \& Ho, John, HKLRD Review Series 2004: Company Law (Hong Kong: Sweet \& Maxwell Asia, 2004).

Uddin, Hamid \& Wong, Ann, "The Stock Market I: The New Issue Market" in Simon Ho et al. (eds.) The Hong Kong Financial System (Oxford: Oxford University Press, 2004).

Wall Street Journal, "HKEx Emerges as Champ in IPOs - for How Long?" (8 December 2009).

Winters, Alan \& Yusuf, Shahid, Dancing with Giants: China, India and the Global Economy (Washington DC: World Bank, 2007). 